\title{
Entrepreneurship Education for Tertiary Institutions in Namibia
}

\author{
Gibbet Murambiwa Magaisa \\ Aldesgate University; Phillipines. \\ Lovemore Matipira \\ Namibia University of Science and Technology, Namibia. \\ Licia Chisoro \\ Acmeret Academic Solutions, South Africa.
}

\begin{abstract}
The main focus of this paper was to explore the main entrepreneurship areas that can be followed in order to achieve the required outcomes for entrepreneurial tertiary institutions in Namibia. Empirical evidence supports the fact that tertiary institution offerings do not meet the expectations of the students. The quantitative research methodology was applied in writing up this paper. The sample size of the paper comprised of 50 respondents.
\end{abstract}

\section{INTRODUCTION}

Entrepreneurship is a new field of study in the academia which has been receiving a steady growth and recognition towards enterprise creation and development as well as generation of an entrepreneurial culture among the students [1], [2]. Empirical evidence supported by scholars and researchers have proven beyond doubt that entrepreneurship education can increase entrepreneurial ability and capabilities in students [3].

There is an urgent need to examine the curricula to review the contents and pedagogical approaches applied to accomplish the desired results. Although it is expensive for researches to be carried out, it is an essential requirement that needs to be done in order to achieve the best possible results. The current results obtained are not good enough as most of the graduates produced by tertiary institutions are unemployed, and are not creating employment. Their contribution to the society is minimal and yet they are supposed to be immensely contributing to the society through employment creation and increased productivity of goods and services. There is therefore a great need to revisit the Universities entrepreneurial education offerings by carrying out thorough researches, as this might help to provide lasting solutions geared towards the production of entrepreneurship graduates who are capable to start up their enterprises and become successful in their business operation. Quality assurance and accreditation of entrepreneurial education programmes needs to be effectively put in place if the tertiary institutions are to produce entrepreneurs who are capable to deliver the results to the nation and the society at large.

Entrepreneurship is a process that generates the discovery of opportunities and harnessing of such opportunities towards the production of goods and services. The entrepreneur in this regard is therefore viewed as an individual who is responsible to discover, evaluate and exploit the discovered opportunities [4].

Kuratko views entrepreneurs as:-

- independent individuals, intensely committed and determined to succeed and who 
work very hard

- confident optimists who strive for integrity

- individuals who burn with the competitive desire to excel and use failure as a learning tool

- individuals who recognize opportunities where others see chaos or confusion

- aggressive catalysts for change within the marketplace

- challengers for the unknown who continuously create the future [5].

Essential ingredients of entrepreneurship include:-

- Willingness to calculate risks - in terms of time, equity or career

- Ability to formulate an effective venture team; the creative skill to mobilize needed resources

- Fundamental skills of building a solid business plan

- The vision and ability to recognize opportunities where others see chaos, contradiction and confusion [5].

There is a distinction between entrepreneurs and small business ownership which are as indicated below:-

- Small Business Owners manage their businesses through stable sales, profits and growth

- Entrepreneurs focus on their efforts on creativity, innovation, profitability and sustainable growth [5]

Entrepreneurship goes beyond the mere creation of a business, it is:-

- $\quad$ Seeking for opportunities

- Taking of calculated risks beyond security

- Having the tenacity to push an idea and see it through to reality

- Entrepreneurship is an integrated concept with the ability to permeate an individual's business in an innovative manner [5].

It's not all business owners who are entrepreneurs. True entrepreneurs are quantified by the qualities that they possess. The qualities of an entrepreneur are:-

- Determination and perseverance

- Drive to achieve

- Opportunity orientation

- Initiative and responsibility

- Persistent problem solving

- Seeking feedback

- Internal locus of control

- Tolerance for ambiguity

- Calculated risk taking

- High energy level

- Creativity and innovativeness

- Vision passion

- Independence

- Team building [5].

\section{LITERATURE REVIEW}

Self-employment has gradually developed as a career option instead of the traditional career paths. Lack of employment is causing governments to shift from the traditional policies to policies that are inclined to small business development as a way of creating employment for 
the graduates to fend for their families. Small and Medium Enterprise (SME) development is the priority for all governments even in developed countries. The advantage of SMEs is that they create jobs, but they are not good enough. There are limitations to SME development as opposed to entrepreneurial development. Entrepreneurship development creates more jobs for many people as opposed to SME owner/managers that focus on creating jobs for themselves and their families. A detailed account of the aforementioned will be discussed in detail in the next stages of this paper.

Education is a vehicle to create mindsets that are geared towards promotion of entrepreneurial skills to the upcoming entrepreneurs. It has been researched and proven that most of the new jobs are created by entrepreneurial small firms. Education is an important means of creating entrepreneurial mindset, skills and attitudes to the aspiring entrepreneur for the benefit of the society [6].

In the USA entrepreneurship courses are offered from undergraduate up to graduate levels. The USA has developed a policy of nurturing and supporting entrepreneurs throughout and as a result USA entrepreneurs have done extremely well in job creation. In a survey carried out by Wilson (2004) the development of European entrepreneurs has been very effective; as a result of European Universities that offer entrepreneurship courses, from undergraduate and postgraduate levels as electives, and this has drastically improved the level of entrepreneurship in the European community.

Tertiary institutions should be involved to more than the disseminating of knowledge and skills necessary for the graduates to obtain a career in a particular field. Tertiary institutions should produce graduates that are capable of generating ideas and follow the generated ideas into fruition through the realisation of ideas into reality. Academic experience, exposure and the curriculum should be a media of disseminating and delivering the attributes. Entrepreneurship is viewed as a type of education that is given to people with a view to develop entrepreneurial qualities, skills and motivation [7].

Shapero and Sokol came up with a model which gave birth to the formation of a business venture. The model assumes that inertia guides human behaviour. If an event guides the inertia, it unlocks a previously undesired behaviour. For example the death of a spouse who had been the bread winner might alter the perception of the remaining spouse to become an entrepreneur. These life path changes are negative displacement, between things and positive pull [8].

Graduates in African tertiary institutions have been inducted and prepared to seek for employment after their graduation [10]. A large number of graduates turn to be employees in organisations, whilst a minority of the graduates turn into entrepreneurship. Friedrich and Visser (2005) note that in South Africa and other African countries the ratio of graduates who turn to entrepreneurship is 1:52, whereas in most of the developed countries it is 1:10 [9]. The ratios reflect a wide disparity of graduates seeking for employment and those that become entrepreneurs. These results are indicators that point out that African tertiary institutions lack entrepreneurial drive. Empirical evidence has supported the fact that entrepreneurial education is the key to employment creation, yet African economies are not taking advantage of job creation through entrepreneurship.

The Global Entrepreneurship Monitor reflected that the education system in Africa lacks entrepreneurship drive. The graduates produced by the tertiary institutions do not have 
entrepreneurial mindsets and would rather opt to be employed, than become entrepreneurs. They have created negative attitudes towards entrepreneurship [11]. Entrepreneurial culture is not cultivated and this makes it difficult for the Governments to fully support entrepreneurship initiatives as tertiary institutions are battling to produce really entrepreneurs who can rise up to the task.

Focus on education about entrepreneurship and for entrepreneurship is a tool to enhance the students' desire and interest in becoming entrepreneurs after graduation [9]. There is need for tertiary institutions to create social platforms that encourage entrepreneurial careers in the education that the students receive. From the onset students should be thoroughly prepared to have an entrepreneurial mindset, as this can lead them to an entrepreneurial career. The involvement of successful entrepreneurs should be encouraged in order for them to provide mentorship to the students, and give them the entrepreneurial mindset and entrepreneurial touch.

In a study conducted by the Federal Ministry of Education from 2005 to 2010 in Nigeria asserts that $71 \%$ of graduates who had studied in Nigerian Universities and other tertiary institutions, were unemployed. Lack of entrepreneurial skills has limited these graduates in joining the entrepreneurial careers [12]. Lack of entrepreneurship skills is the main root cause of unemployment on graduates [13]. Tertiary institutions in Africa, need to provide offerings that can help the graduates to organize their resources and ideas to create employment for themselves and others too. A successful entrepreneur can create over thousands of jobs as opposed to a small business owner who can create three or four jobs.

Tertiary institutions have developed curriculums, and have failed to meet the challenge. They churn out entrepreneurship graduates annually who are unemployed, unable to start up their own business ventures and provide employment to others [14]. Ironically unemployment is rife and poverty is on the rampage, yet entrepreneurial drive should help to curb this perennial problem affecting the continent.

In a research carried out by Friedrich on an entrepreneurship undergraduate class, the results reflected a change of mindsets of the students by engaging in self-employment as a viable alternative instead of job seeking Entrepreneurship students were given the opportunity to identify and start up business ventures whilst still at the University. On graduating the students had to just continue with their projects [9].

Alberti et al., identified five critical variables that have a strong bearing towards entrepreneurship education development, these are ideally the variety of audiences and objectives, entrepreneurship course contents, pedagogies and assessment methods. Figure 1 below presents these five variables and their relations [15].

Entrepreneurship education is dependent upon the learning audiences 1., assessment can only be effective once the goals and objectives are set 2., contents can be accurately defined once goals and objectives have been set 3 ., and these would be dependent on the audience 4 ., pedagogies can be rightly chosen depending on the entrepreneurship programme course content 5., and audiences 6., assessments would be hinged upon both contents 7., and pedagogies 8, [15]. 


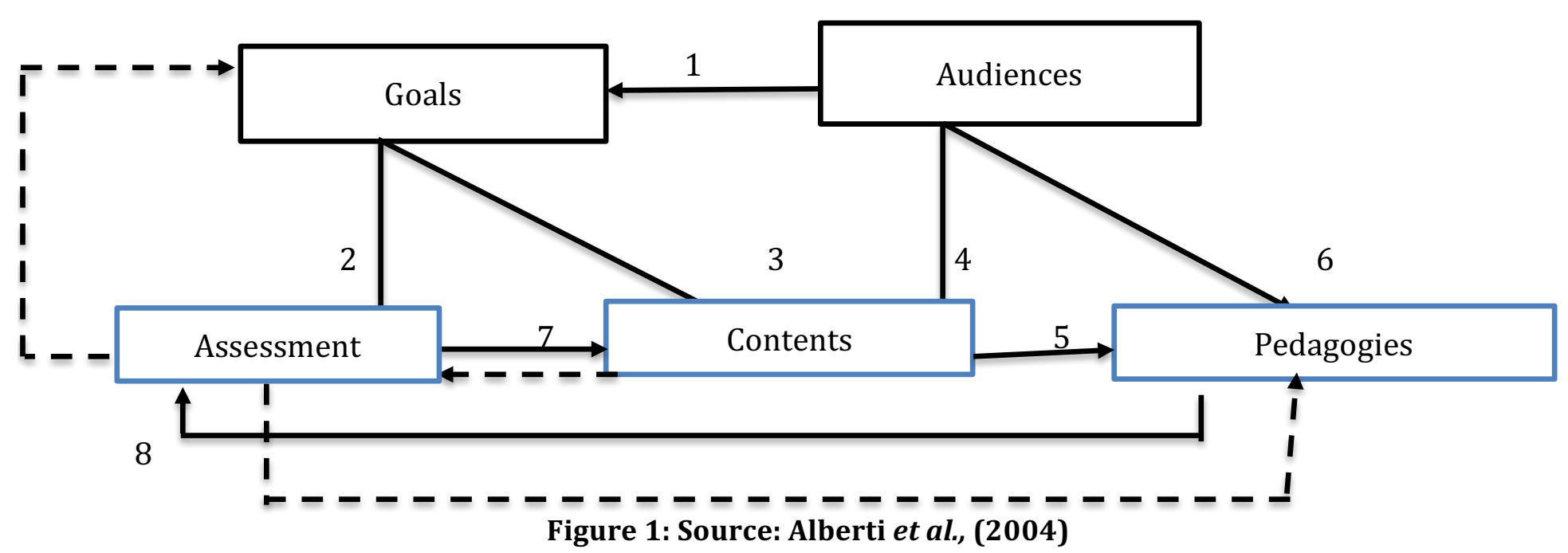

The five core variables and their relationships have a critical impact towards effective learning process development. Embracing these key variables and their relations will definitely have a significant effect to the learning process development of the entrepreneurship student [15].

\section{RESEARCH METHODOLOGY}

The quantitative research methodology was adopted in this paper. The sample size of this study comprised of 50 respondents represented as follows:-

$\begin{array}{lc}\text { Entrepreneurship Lecturers } & 10 \\ \text { Entrepreneurship Students } & 15 \\ \text { Entrepreneurship Graduates } & 15 \\ \text { Entrepreneurs } & \underline{10} \\ \text { TOTAL NUMBER OF RESPONDENTS } & \underline{\mathbf{5 0}}\end{array}$

\section{ANALYSIS AND DISCUSSION OF RESULTS}

A Pearson Correlation Analysis was carried out to determine the relationship that exists among the variable as indicated on Table 1 below:-

Table 1 Pearson Correlation Analysis

\begin{tabular}{|c|c|c|c|c|}
\hline & & $\begin{array}{l}\text { Entrepreneur- } \\
\text { ship education } \\
\text { and job creation }\end{array}$ & $\begin{array}{l}\text { Postgraduate } \\
\text { entrepreneurship } \\
\text { education effect } \\
\text { on job creation }\end{array}$ & $\begin{array}{l}\text { Effects of } \\
\text { entrepreneurship } \\
\text { education on job } \\
\text { creation }\end{array}$ \\
\hline $\begin{array}{l}\text { entrepreneurship } \\
\text { education and job } \\
\text { creation }\end{array}$ & $\begin{array}{ll} & \text { Pearson Correlation } \\
& \text { Sig. (2-tailed) }\end{array}$ & 50 & $\begin{array}{r}.949^{* *} \\
.000 \\
50\end{array}$ & $\begin{array}{r}.962^{* *} \\
.000 \\
50\end{array}$ \\
\hline $\begin{array}{l}\text { Postgraduate } \\
\text { entrepreneurship } \\
\text { education effect on } \\
\text { job creation }\end{array}$ & $\begin{array}{l}\text { Pearson Correlation } \\
\text { Sig. (2-tailed) } \\
\mathrm{N}\end{array}$ & $\begin{array}{r}.949^{* *} \\
.000 \\
50\end{array}$ & 1 & $\begin{array}{r}.960^{* *} \\
.000 \\
50\end{array}$ \\
\hline $\begin{array}{l}\text { Effects of } \\
\text { entrepreneurship } \\
\text { education on job } \\
\text { creation }\end{array}$ & $\begin{array}{l}\text { Pearson Correlation } \\
\text { Sig. (2-tailed) } \\
\mathrm{N}\end{array}$ & $\begin{array}{r}.962^{* *} \\
.000 \\
50\end{array}$ & $\begin{array}{r}.960^{* *} \\
.000 \\
50\end{array}$ & 50 \\
\hline
\end{tabular}

**. Correlation is significant at the 0.01 level (2-tailed). 
Table 1 above indicates that there is a strong, positive correlation between entrepreneurship education and job creation and postgraduate entrepreneurship education effect on job creation $r(48)=.95, p<.01$.

Table 1 above suggests that there is a strong, positive correlation between entrepreneurship education and job creation and effects of entrepreneurship education on job creation $r(48)=$ $.96, p<.01$.

There is a strong, positive correlation as depicted in Table 1 above, between postgraduate entrepreneurship education effect on job creation and entrepreneurship education and job creation $r(48)=.95, p<.01$.

There is a strong, positive correlation as indicated in Table 1 above, between postgraduate entrepreneurship education effect on job creation and effects of entrepreneurship education on job creation $r(48)=.96, p<.01$.

There is a strong, positive correlation as depicted in Table 1 above, between effects of entrepreneurship education on job creation and entrepreneurship education and job creation $r(48)=.96, p<.01$.

There is a strong, positive correlation as noted in Table 1 above, between effects of entrepreneurship education on job creation and postgraduate entrepreneurship education effect on job creation $r(48)=.96, p<.01$.

The results strongly support the importance of entrepreneurship education in tertiary institutions. There is therefore need for the development of curriculums that focus on developing students to be able to create enterprises and create employment rather than focus on seeking for employment prospects.

\section{CONCLUSIONS AND RECOMMENDATIONS}

There is need to revamp entrepreneurship education offerings within the higher education systems. Tertiary institutions are encouraged to change current policies, practices and offerings, including:-

- Seeking more detailed information from students and using this information to inform curriculum development;

- Building cumulative pre-incubation time into the curricula to allow students to build and develop a business idea;

- Preparing students for "risk" and "ownership"; and

- Providing entrepreneurial experiences for students; making it easier for students to "drop-in" and "drop-out" of education after graduation [16].

Formal education has obscured the hidden curriculum of family experience and exposure to entrepreneurial role models which also contribute towards the development of entrepreneurs. Showering of general formal training on would-be entrepreneurs has proven to be less helpful than hoped for. The process of developing skills in small enterprises ought to be of a less formal and more hands-on approach.

Assessments are in the form of assignments, formal exams and questionnaires, this is not good enough in entrepreneur development. There is need for students to create and establish opportunities in order to gain a sense of accomplishment. Tertiary institutions do not provide this platform to entrepreneurial students. There is need to provide an entrepreneurial context 


\section{or environment.}

Entrepreneurs generally learn mainly from other entrepreneurs through sharing ideas, making useful social contacts, an informal process that requires neither state intervention nor taxpayers' money. Most of the tertiary institutions do not involve entrepreneurs or role models in curriculum development.

Attention needs to be paid for students to develop their business skills and understanding, much attention has to be paid to the development of entrepreneurial skills, attributes and behaviours. This should be achieved through the introduction of modules and courses specifically designed to develop students' awareness and inculcate entrepreneurial characteristics to the students.

Tertiary institutions need to institute cultural changes as this will be critical in understanding students' entrepreneurial needs. An institutional fit between tertiary institution offerings, societal needs and the needs of the students has to be put in place in order to address the plight of the students and the society at large.

Friedrich and Visser have recommended the following for the improvement of entrepreneurial education:-

- Entrepreneurship training must be practically based. It must be hands on experiences as opposed to the current academic rigour.

- Duration of entrepreneurship courses should be longer as opposed to short courses as in business school training offerings. It takes longer to change attitudes, and training over a longer period of time to yield positive outcomes [9].

\section{References}

Kuratko, D.F., Entrepreneurship Education: Emerging Trends and Challenges for 21st Century. Coleman Foundation White Paper Series for the U.S. Association of Small Business and Entrepreneurship, Available on: http// www.usasbe.org/pdf/CWP-2003-kuratko.pdf

Solomon, G.T., Duffy, S., \& Tarabishy, A., The State of Entrepreneurship Education in the United States: A National Survey and Analysis. International Journal of Entrepreneurship Education. 2000. 1(1):65-86.

Gorman, G., Hanlom, D., \& King, W., Some Research Perspectives on Entrepreneurship Education and Education for Small Business Management: A Ten-Year Literature Review. International Small Business Journal, 1997. 15(3):56-77.

Shane, S., \& Venkataraman, S., The Promise of Entrepreneurship as a Field of Research. The Academy of Management Review, 2000. 25(1):217-226.

Kuratko, D.F. Entrepreneurship, Theory, Process, Practice. Mason, OH. USA. South-Western Cengage Learning, 2014. Available on: http://www.flashcardmachine.com/entr-187.html

Niyonkuru, R., Entrepreneurship Education at Tertiary Institutions in Rwanda: A Situational Analysis. Published Thesis University of the Western Cape, R.S.A. Available at:-

https://www.google.com.na/?gws_rd=cr\&ei=H1xxWNfTG4W2sQHjvKJI\#q=niyonkuru+r.+entrepreneurship+educ ation+at+tertiary+institutions+in+rwanda:+a+situation+analysis+university+of+the+western+cape+rsa

Fallows, S., \& Steven, C., Building Employability Skills into the Higher Education Curriculum: A University-wide Initiative. Educ. Train. Jo, 2000. 42(2)

Shapero, A., \& Sokol, L., The Social Dimensions of Entrepreneurship. In C. Kent, Sext on, D., Ves per, K. (Ed.), Encyclopedia of Entrepreneurship: 1982. 72-90.Englewood Cl iffs, New Jersey: Prentice-Hall, Inc.

Louw, L., van Eeden, S.M., Bosch, J.K., \& Venter, D.L.., Entrepreneurial Traits of Undergraduate Students at Selected South African Tertiary Institutions. Int. J. Enterpr. Behav. Res, 2003. 9(1): 5-26. 
Friedrich, C., Visser, K., The challenges of entrepreneurship education at university: Evidence from a Longitudinal Study Survey. Working paper, 2004. University of Western Cape

Global Entrepreneurship Monitor, Executive Report. UK, 2001.

Ekpo, P., An Evaluation of Graduate unemployment among University Students in Nigeria. Daily Independent, 2010. February 7, p.10.Kanski, J.J., Clinical ophthalmology. 6th edition ed. 2007, London: Elsevier Health Sciences (United Kingdom). 952

Adebisi, T.A., \& Oni, C.S., Assessment of National Directorate of Employment Training Programme to the needs of the Trainees in South West Nigeria. International Journal of Vocational and Technical Education, 2012. 4(3) 29-37.

Kirby, D.A., Entrepreneurship education: can business schools meet the challenge? Education and Training Journal, 2004. 46(8/9): 510-519.

Alberti, F., Sciasca, S., Poli, A., Entrepreneurship Education: Notes on Ongoing Debate. Proceedings of the 14th Annual IntEnt Conference. University of Napoli Frederico II, 2004, 4-7 July, Italy.

Collins, L., Hannon, P.D., \& Smith, A., Enacting Entrepreneurial Intent: The Gaps between Student need and Higher Education Capability. Educ. Train., 2004. 46(8/9): 454-463. 